\title{
Determining PAUD Teachers' Capability To Develop Sociable Learning Model Through Traditional Sundanese Games.
}

\author{
Solihin Ichas Hamid ${ }^{1}$, Tuti Istianti ${ }^{2}$, Mohamad Helmi Ismail ${ }^{3 *}$ \\ 1,2,3 Early Childhood Teacher Education Study Programe, Indonesian University of Education. \\ ${ }^{*}$ Corresponding Author: \\ Email: helmiismail321@gmail.com
}

\begin{abstract}
.
The application of the Sociable Learning Model has strong relevance as a solution to the problem of early childhood social behavior these days. Meanwhile, the role of Early Childhood Education teachers who have crucial value for Early Childhood cannot be well maximized due to the various restrictions as an effort to handle COVID-19 cases in Indonesia. The implementation of training on the development of the Sociable Learning Model through Traditional Sundanese Games in West Java requires a mapping foundation of the teacher's experiences so that it can provide some meaningful and appropriate resources for further treatments. To accommodate the required data collections, the holding of the workshop is needed to accommodate the variety of teacher's perceptions on the Social Citizenship development efforts in the Early Childhood Education setting that can be a starting point to find out the teacher's basic understanding of the development of social civic behavior in PAUD. The exploration effort is has been carried out by spreading questionnaires to workshop participants to collect various teacher perceptions related to innovations in the development of Social Citizenship Behavioral Skills (PrSKn) based on traditional Sundanese games.
\end{abstract}

Keywords: PrSKn, Sundanese traditional games, Teachers' Competency.

\section{INTRODUCTION}

Various problems of children's social-emotional development have recently become more and more complicated by the regulation of distance learning programs caused by the COVID-19 pandemic. That regulation technically affecting the learning program that is usually being conducted in most of the schools these days. It goes without saying that the regulations that aimed to halt the outbreaks of the COVID-19 virus have taken a great learning loss in most education programs especially in the Early Childhood Education scope. The loss of a socio-emotional environment in the scope of AUD learning is becoming common while learning from home programs in these present days. These occurrences are contradicting with the vision of the early Childhood Education program based on Montessori's opinions [1], which affirms the importance of the social environment in addition to the role of teachers and parents. Furthermore, the loss of the social environment in the study Frąckowiak-Sochańska (2020) has even given a rise to a tendency of mental disorders referred to as General Adaptation Syndrome (GAS).

...the pandemic undeniably burdens the global population with stress, the consequences of which are: heightening the anxiety to the extent 
that meet formal criteria of anxiety disorders, an increase of depressiveness (as the consequences of chronic anxiety and social isolation), difficulties in controlling one's anger and other emotions (resulting from the frustration of various needs that cannot be fulfilled due to the restrictions).

\section{Frąckowiak-Sochańska [2]}

During the social restriction where most people were urged to stay at their homes, their social interactions becoming very limited, and having more leisure time did not very suffice their needs. Besides making more and more people being lazier, during their staycations people becoming more exposed to the TV shows and Internetbased media. These recent tendencies not only affecting adults' behavior but the children also experiencing the same changes and the worst thing about these behavior patterns is it leads people to feel more stressed and bored and leading them to some mental disorders just like what was stated by Frąckowiak-Sochańska [2].These disturbances that specifically addressed the early children regarding this study is considering how the children become more exposed to the bad news in TV shows or various types of social media that is not supposedly accessed by them. Most of them are experiencing emotional saturation and mental disorders that make it more difficult to concentrate, restless, and impatient. This suggests the children's social-emotional development finds additional barriers if compared with the period before the onset of the pandemic.

Emotional disorders in children in the form of fear, anxiety, or anger actually can affect the balance of growth in their bodies and their developmental rates. In Istianti, et al. [3] mentioned that various disorders as mentioned could affect the children's motor and mental skills. In addition to specifically related effects to the children's development, the psychological impact of the existing COVID-19 pandemic also affects changes in social behavior in society in general. Other the specifically affecting children's development the social impact of the current pandemic disrupting the social environment that reducing the children's opportunities to develop.Furthermore, as stated by Istianti, et al. [3] children's behavior can strongly be affected by the environment in which they grow. The environment can give a great deal of influence to the children considering their development is heavily influenced by the social order taken by someone, both from the family environment, school, and community environment. Regarding the children's natural behavior that was stated earlier, the efforts to develop children's competence, one of which is pro-social behavior as mentioned in Article 13 of PerMenDikBud no. 137 of 2014 [4], should be done in a way that builds interactivity, inspiring, fun, contextual, and child-centered. In addition, Lee \& Lai [5] is also said that the student-centered paradigm is not enough. Having a paradigm that learning must be student-centered is not enough. The current urgency lies in how to develop higher-order thinking skills from the students' perspectives. 
Within these circumstances, the sociable learning model that relying heavily on the children's initiatives to build their own knowledge and exercising their skills in the term of their choosing in the concrete social interactions, considered has strong relevance in educating children to be a good citizen, having positive behavior, independent, disciplined, honest, polite, and well taught. Within the sociable learning model, all of those activities are being integrated within the setup of play activities that correspond to the children's natural drives during their early stage of development. The student-centered learning activity assembled within the model provides many opportunities for children to develop their thinking skills independently based on values.Meanwhile, the utilization of traditional games in the designed activities to manage the children's Social Citizenship Behavior also has strong relevance to the actual molar value for the children. The familiarity of traditional games in the learning activity can give the children a better sense of competence so then the children will be more motivated in their learning process. The effort to build the children's sense of competence is one of the important strategies in encouraging children's motivation during their learning process as stated in the self-determination theory.

Ryan \& Deci [6], described that building one's motivations, it requires giving the three main psychological needs such as the feeling free to act, the feeling capable, and the feeling connected. One of the many traditional games acknowledged in Indonesia that can be used as a bridge for the development of children's Social Citizenship Behavior is the variety of traditional games in west Java.On the other hand, if we observe the learning practices that occur in the field, there are still many learning patterns that tend to be centered on the teachers in which will only provide a variety of rules and punishments instead of building good character. These kinds of learning systems, later on, will only give intensify the seeds of behavioral deviations and distrust in the children's minds. In addition, distance learning that is commonly done these days reduces the quality of children's interactions with teachers who are forced to give more instruction and reduce children's initiative in learning. Not only the children becoming more focused on their teacher's instructions, but they also lose the chance to interact with their peers to grow together. These various obstacles reflect the level of difficulty that exists in implementing the encouragement of Social Citizenship Behavioral Skills and also show a high urgency for the implementation of training programs to develop teacher abilities relevant to the study in question. The Sociable Learning Model is a model that can be developed in PAUD to meet the needs of children's educational services, especially for the purpose of social behavioral development. Within this model, the learning activities are fully directed to develop the three developmental aspects, namely aspects of attitude, knowledge, and skills as a whole, meaning that the development of one aspect cannot be separated from the other aspect.

Teachers as practitioners in the field are expected to be able to apply the Sociable Learning model to create a more effective, efficient, and useful learning 
process. Meanwhile, based on previous research data, in addition to the problem of interaction barriers, because learning is done online, teachers also tend to be less accustomed to applying student-centered learning. An overview related to the professional competence of Early Childhood Education teachers and the conditions of the existing era urges an immediate resolution and demands efforts to develop their competence as mentioned by Sujiono [1] on Government Regulation No. 19 of 2005: National Standards of Education Chapter VI which describes the variety of competencies that are required to be mastered by teachers, especially those related to their professional competence. Therefore, directed training efforts are needed in the form of workshops and training. Workshop activities are an effort to find a common resolution related to the problems that are being faced. The application of this method will provide an overview of the needs of skills that are relevant to what is needed by teachers in dealing with existing problems. With some descriptions mentioned, this article aims to outline the variety of early readiness of teachers related to problems faced in the development of children's civic social behavior with the obstacles of the era that require the enactment of online learning.

\section{METHODS}

This article outlines the community service program carried out by focusing on the workshop methods. The workshop is conducted to discuss various problems in developing the children's Social Citizenship Behavioral Skills experienced by teachers in the Bandung area, associated with the integration of traditional Sundanese games. Based on the variety of statements collected, further methods like training will be conducted in designing and practicing learning plans based on the Sociable Learning Model development model.

\section{RESULT AND DISCUSSION}

\section{a. Result}

All of the teachers surveyed said that they had no difficulty in the general learning practice that had been done before. Of the six questions related to their experience in teaching, all teachers answered it with no difficulty. On the other hand, if it is associated with Social Citizenship Behavioral Skills development efforts within the scope of Early Childhood Education, teachers admit that they are experiencing some difficulties so that their answers are more varied. And if it is grouped in a group of learning practices related to Social Citizenship Behavioral Skills development efforts, the most difficulty experienced by teachers is about how to guide children in socializing with their peers however, most of the teachers admit that they have no difficulty in building children's appreciative attitudes. That way, it can be concluded that efforts to build positive behavior of children during social interaction are considered difficult for teachers. 


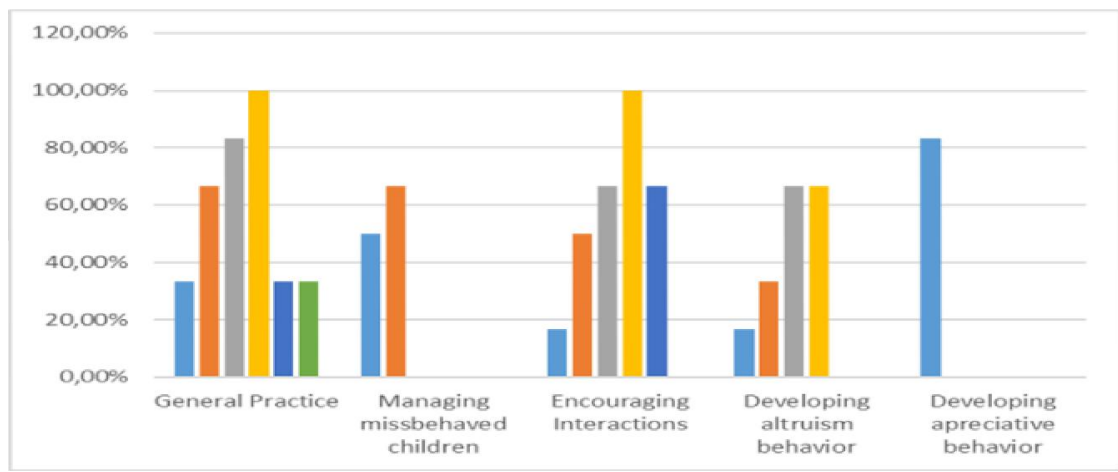

Fig 1. Difficulties experienced by the Teachers

Meanwhile, of the difficulties experienced, teachers have a variety of visions on how to overcome the difficulties they experience in teaching children related to efforts to develop social civic behavior and the use of traditional games. From the results of the survey obtained, all teachers have optimistic initiatives and views to overcome problems in the learning process that they hold. In addition to outlining opinions on the implementation of Social Citizenship Behavioral Skills development, teachers have also tried to make several innovation efforts in their learning program. Of the 12 questions given, all teachers gave a positive response but on the contrary, they did not know much about Social Citizenship Behavioral Skills in particular.

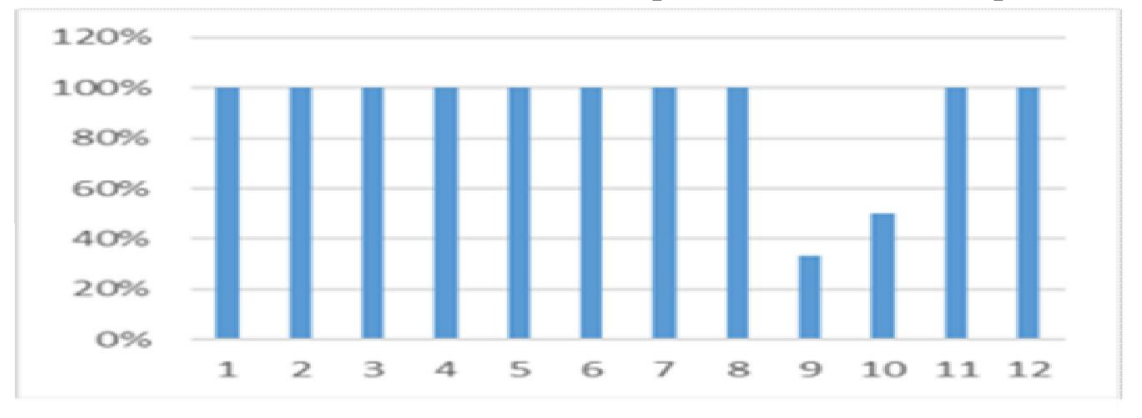

Fig 2. Teachers' vision of innovations

Meanwhile, if it is related to their experience of success in making innovation, the teachers argue that they have achieved success in innovations that are done but not with the process of discovering the concept of citizenship. Based on several statements from the respondents it can be concluded that in general, teachers have no difficulty in carrying out their duties as teachers. However, they have difficulty when it comes to the efforts in developing children's social behaviors that are still unfamiliar to them. The Efforts in developing social behavior in general as the part of social-emotional aspect of children are common things for teachers because they also admitted that they often develop children's skills in that domain but are not specific to the social behavior of citizenship. 
International Journal Of Community Service

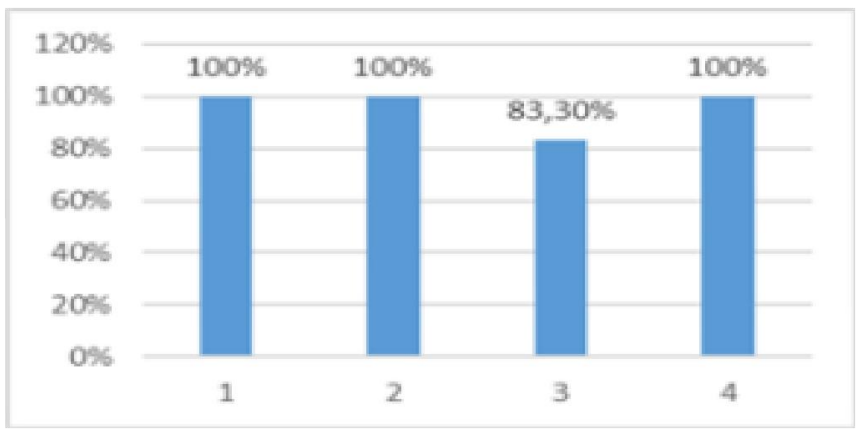

Fig 3. Innovations success rate

The development of competence in the social-emotional aspect is not unusual for teachers to do. It is also one of the demands of professional competence of PAUD teachers as mentioned in the Regulation of the Minister of Education and Culture No. 137 of 2014 on National Standards of PAUD, [4] among others, including, Studying the basic concepts of science in mathematics, science, language, social studies, art, and religion in accordance with the needs, stages of development and psychomotor early childhood, formulating the objectives of each development activity, Analyze early childhood development in every area of development, etc.

\section{b. Discussions}

Concerning Social Citizenship Behavioral Skills development efforts, some teachers have experienced some difficulties especially in terms of building children's social behavior competence related to the process of negotiation, interaction, and social care. Efforts to develop social behavior as mentioned by Istianti, et al., [3] refer to the relationship of human interaction with each other to live together, help each other, and socialize. Many things can indeed be causing a variety of difficulties in question but, when viewed from the children's personal nature related to social behavior, actually the process of identifications are the easiest thing to get the children being used to the preferred behavior. Istianti, et al., [3] by quoting opinions (Dariyo, 2005, p. 114). Mention that children can begin to develop their social behavior by absorbing the values, norms, and ethics of their social culture, especially from their parents. The absorption process is actually an imitation effort made by the children towards the figure who is considered as a model by the children. The identification process not only applies to social skills but also to the character-building of citizenship in the children.

This can be attributed to the opinion of Samsuri [7] which confirms that Citizenship Education has dimensions that cannot be separated from the aspects of the formation of the character and public morality of citizens.Regarding the developed circularly designed models that are operated strategically and contextually, namely: Building Paradigms, Agreeing on rules, Participating as players, Giving appreciation, Reflection in the context of play [8] those identifications processes can happen during children's learning activities. With regard to models that have been developed as an 
effort to develop the character of citizens for the early children, various development can be done by play activities that make room for children to optimize their social development. For the children, play can encourage them to find some experiences in making choices, solving problems, communicating, sharing, empathizing, responsibility, self-control, negotiating, and problem-solving. A sociable learning model can facilitate the children in building their character of citizenship who are skilled in society. One of the main foundations of the Sociable Learning model in the development of Social Citizenship Behavioral Skills is its integration with traditional game content from where learners grow and develop.

Based on previous research, the development carried out shows the results of findings that show important changes and are considered appropriately related to improving the quality of learning processes in early childhood education, especially in terms of children's Social Citizenship Behavioral Skills. [3]. By means of some consideration regarding the findings of data on the response of teachers who are not familiar with the efforts of developing Social Citizenship Behavioral Skills within the scope of early children, the training of the development of sociable learning model will be able to assist teachers in their duties in PAUD, especially in distance learning conditions. Some of the difficulties experienced by the teachers in developing a child's pro-social skills can be reinforced by applying models that have been developed in previous research. The sociable learning model product design can be used as a guideline for teachers in designing learning that allows the emergence of Various activities of children in finding values (discovery learning), exploration through cooperation, communication, skills in terms of rules, skills in giving positive appreciation.

\section{CONCLUSION.}

From several reviews of the survey results conducted, it can be concluded that, although in general, they do not have trouble, in the scope of Social Citizenship Behavioral Skills development efforts, some teachers have difficulty especially in the terms of building children's social behavior related to the process of negotiation, interaction, and social care. Likewise, with innovation efforts, teachers have good views and plans, many of whom have tried to innovate by identifying problems in learning, finding relevant information, and conducting trials, and most admit to having succeeded however, all of them are done in a general scope, not specific in Social Citizenship Behavioral Skills development efforts.

\section{ACKNOWLEDGMENT}

The implementation of workshops and training conducted in the framework of community service is supported by LPPM Universitas Pendidikan Indonesia and several kindergartens in Bandung that are incorporated as partners. 


\section{REFERENCES}

[1] Sujiono, Y., N., (2009) Basic Concept of Early Childhood Education, transl. Konsep Dasar Pendidikan Anak Usia Dini. PT. Index, Jakarta

[2] Frąckowiak-Sochańska, M., (2020) Mental Health in Pandemic Times. SOCIETY REGISTER 2020 / 4(3): 67-78 ISSN 2544-5502 DOI: 10.14746/sr.2020.4.3.03

[3] Istianti, T., Hamid, S., I., Abdillah, F., Ismail, M., H., (2019) Developing Social Behavior citizenship for Early Childhood, 2nd eds. Transl. Mengembangkan Perilaku Sosial Kewarganegaraan untuk Anak Usia Dini, $2^{\text {nd }}$ eds. Bandung, UPI Cibiru Campus.

[4] MENDIKBUD (2014) Permendikbud no. 137 of 2014; National Standard of PAUD. Transl. Permendikbud no. 137 tahun 2014; Standar Nasional PAUD. Retrieved from https://luk.staff.ugm.ac.id/atur/bsnp/Permendikbud137-2014StandarNasionalPAUD.pdf

[5] Istianti, T., Hamid, S., I., Abdillah, F., Ismail, M., H., (2019) Teachers' Outlooks on Social Citizenship Behaviour Learning Model: A grounded theory. (pp. 392-395). Atlantis Press.

[6] Ryan, R., M., \& Deci, E., L (2000) Self-Determination Theory and the Facilitation of Intrinsic Motivation, Social Development, and Well-Being, the American Psychological Association, Inc. 0003-066X/00/\$5.00 Vol. 55, No. 1, 68-78 DOI: 10.1037110003066X.55.1.68. pp. 68-73

[7] Samsuri (2011). Citizen Character Education. transl. Pendidikan Karakter Warga Negara. Yogyakarta: Diandra Pustaka

[8] Istianti, T., Hamid, S., I., Ismail, M., H., Abdillah, F., Mirawati (2020) Sociable Model in Distance Learning For Early Childhood. Transl. Model Sociable Dalam Pembelajaran Jarak Jauh Bagi Anak Usia Dini. Bandung, Rizqi Press. 